\title{
PROGRAM SEKOLAH ADIWIYATA DALAM PENGEMBANGAN SOSIO-EMOSIONAL ANAK USIA DASAR DI SDN NGUPASAN YOGYAKARTA
}

\author{
Muhammad Majdi \\ Program Studi Pendidikan Guru Madrasah Ibtidaiyah \\ Sekolah Tinggi Ilmu Al-Quran (STIQ) Amuntai \\ J1. Rakha Pakapuran, Amuntai Utara Kab. Hulu Sungai Utara, Kalimantan Selatan \\ E-mail: muhammadmajdi755@gmail.com \\ Website: https://jurnal.uin-antasari.ac.id/index.php/adzka \\ Received: 16 September 2019; Accepted: 10 Januari 2020; Published: 12 Januari 2019
}

\begin{abstract}
The development of positive or good social emotions is a predictor of success in the academic, cognitive, social and emotional fields of a child's future life. This research was conducted at Ngupasan Elementary School in Yogyakarta so that researchers could see the extent of the results of the Adiwiyata program in children's social emotional development. This type of research is field research using a Qualitative Approach and descriptive method. The results showed that the Adiwiyata school program included (1) environmentally sound policies. (2) Implementation of an environment-based curriculum. (3) Participatory-based environmental activities. (4) Management of environmentally friendly supporting facilities. The contribution of the implementation of the Green School Program in the development of socio-emotional basic age children is that children are able to control emotions, help and enjoy working together and be responsible, responsive, can play games using rules and can create them, care, sensitive, more trusting and independent, tied to the figure of a parent.
\end{abstract}

Key Words: adiwiyata school program; social development of basic age child emotions.

\begin{abstract}
ABSTRAK
Perkembangan sosial emosional yang positif atau baik merupakan prediktor untuk kesuksesan dalam bidang akademik, kognitif, sosial dan emosional dalam kehidupan anak selanjutnya. Penelitian ini dilaksanakan di SDN Ngupasan Yogyakarta agar peneliti dapat melihat sejauh mana hasil pencapaian dari program Adiwiyata dalam pengembangan sosio emosional anak. Jenis penelitian ini adalah Field research menggunakan Pendekatan Kualitatif dan metode diskriptif. Hasil penelitian menunjukkan bahwa program sekolah Adiwiyata meliputi (1) Kebijakan berwawasan lingkungan. (2) Pelaksanaan kurikulum berbasis lingkungan. (3) Kegiatan lingkungan berbasis partisipatif. (4) Pengelolaan sarana pendukung ramah lngkungan. Kontribusi dari Implementasi Program Sekolah Ramah Lingkungan dalam pengembangan sosio emosional anak usia dasar adalah anak mampu mengontrol emosi, membantu dan senang bekerjasama serta bertanggung jawab, responsif, dapat memainkan permainan memakai aturan dan dapat menciptakannya, peduli, sensitif, lebih percaya dan mandiri, terikat pada figur orang tua.
\end{abstract}

Kata Kunci: program sekolah adiwiyata; pengembangan sosio emosional anak usia dasar.

\section{PENDAHULUAN}

Sekolah Adiwiyata atau sekolah peduli dan berbudaya lingkungan sebagaimana disebutkan dalam peraturan menteri lingkungan hidup nomor 2 pasal 1 Tahun 2009 (tentang pedoman pelaksanaan program Adiwiyata) merupakan program kerja berlingkup yang dikelola oleh kementerian lingkungan hidup dalam rangka mewujudkan pengembangan pendidikan lingkungan hidup dan mendorong terciptanya pengetahuan dan kesadaran warga 
sekolah dalam upaya pelestarian lingkungan hidup yang secara garis besar bertujuan untuk mengubah karakter warga sekolah menjadi peduli, berwawasan dan berbudaya lingkungan. Perilaku peduli lingkungan dapat dilakukan dengan menghargai dan mencintai alam yang ditunjukkan dengan selalu menjaga kelestarian lingkungan sekitar, tidak membuang sampah sembarangan, melaksanakan kegiatan yang berkaitan dengan kepedulian lingkungan (Rahmawati dan Suwanda, 2015).

Pendidikan lingkungan hidup diimplementasikan dalam bentuk program Kementerian Lingkungan Hidup yang merupakan implementasi Permen Lingkungan Hidup No. 02 tahun 2009. Program ini merupakan suatu bentuk penghargaan yang diberikan oleh pemerintah kepada lembaga pendidikan formal yang dinilai berjasa dalam mengembangkan pendidikan lingkungan hidup yang disebut dengan program Adiwiyata. Kata Adiwiyata berasal dari kata Sansekerta yaitu "Adi" bermakna: besar, agung, baik, sempurna. "Wiyata" bermakna: tempat di mana seseorang mendapat ilmu pengetahuan, norma. Jadi, Adiwiyata mempunyai pengertian atau makna: tempat yang baik dan ideal dimana dapat diperoleh segala ilmu pengetahuan dan berbagai norma serta etika yang dapat menjadi dasar manusia menuju terciptanya kesejahteraan hidup kita dan menuju cita-cita pembangunan berkelanjutan. Adiwiyata dicanangkan untuk mendorong dan membentuk sekolah-sekolah di Indonesia agar dapat turut melaksanakan upaya pemerintah menuju pelestarian lingkungan dan pembangunan berkelanjutan bagi kepentingan generasi sekarang maupun yang akan datang (Rismawati, 2013). Program Adiwiyata merupakan langkah nyata sebagai kerja sama Kementerian Lingkungan Hidup dan Kementerian Pendidikan dan Kebudayaan untuk menciptakan pembangunan berwawasan lingkungan hidup.

Perkembangan sosio emosional adalah proses berkembangnya kemampuan anak untuk menyesuaikan diri terhadap dunia sosial yang lebih luas. Dalam proses perkembangan ini anak diharapkan mengerti/memahami orang lain yang berarti mampu menggambarkan ciricirinya, mengenali apa yang dipikirkan, dirasa dan diinginkan serta dapat menempatkan diri pada sudut pandang orang lain tersebut tanpa kehilangan dirinya sendiri. Selama masa ini, anak banyak meluangkan waktunya dalam berinteraksi dengan teman sebaya. Orangtua hanya mempunyai waktu sedikit dengan anak-anak selama masa kanak-kanak akhir ini, tetapi maih merupakan pelaku sosialisasi yang kuat dan penting (Soetjiningsih, 2014).

Dalam bukunya Carolyn Meggit (2012) mengklasifikasikan Perkembangan Sosial Emosional Anak pada usia 7-12 tahun ke atas dengan rincian sebagai berikut

Tabel 1

Perkembangan Sosial Emosional Anak pada Usia 7-8 Tahun

\begin{tabular}{|l|l|}
\hline Umur/Tahun & Perkembangan Sosial Emosial \\
\hline 7-8 Tahun & Menginternalisasi aturan sosial dalam budayanya \\
\cline { 2 - 3 } & $\begin{array}{l}\text { Mereka telah mampu membedakan antara aturan sosial dan } \\
\text { aturan dalam menunjukkan emosi }\end{array}$ \\
\cline { 2 - 3 } & Menanggapi setiap penjelasan dengan fositif \\
\cline { 2 - 3 } & $\begin{array}{l}\text { Mulai memiliki pemahaman sosial yang lebih luas, dapat } \\
\text { merasa terganggu dengan program pemberitaan yang } \\
\text { menampilkan kekerasan atau bencana alam }\end{array}$ \\
\cline { 2 - 3 } & $\begin{array}{l}\text { Dapat mengikuti sebuah kejadian dari awal hingga akhir serta } \\
\text { sensitif terhadap kebutuhan orang lain }\end{array}$ \\
\cline { 2 - 3 } & $\begin{array}{l}\text { Mampu bertanggung jawab serta suka membantu anak-anak } \\
\text { yang lebih kecil serta ada keinginan kuat untuk bisa diterima } \\
\text { antara anak-anak lain atau diantara orang-orang dewasa }\end{array}$ \\
\cline { 2 - 3 } & Dapat menyesuaikan perilakunya mengikuti situasi yang ada \\
\cline { 2 - 3 } & Dapat memainkan permainan yang memakai aturan \\
\hline
\end{tabular}




\begin{tabular}{|l|l|}
\hline & $\begin{array}{l}\text { Dapat membantah dan berdebat dengan sudut pandangnya } \\
\text { sendiri }\end{array}$ \\
\cline { 2 - 3 } & Lebih percaya dan mandiri \\
\cline { 2 - 2 } & Bersahabat dan bekerjasama \\
\hline $\begin{array}{l}\text { Sering kali menunjukkan kemampuan dalam mengontrol } \\
\text { perasaan, namun ada saatnya bersikap egois dan bertengkar } \\
\text { dengan anak-anak lain }\end{array}$ \\
\hline
\end{tabular}

Tabel 2

Perkembangan Sosial Emosional Anak pada Usia 8-9 Tahun

\begin{tabular}{|c|c|}
\hline $\begin{array}{l}\text { Umur/Tahun } \\
\text { 8-9 Tahun }\end{array}$ & Perkembangan Sosial Emosial \\
\hline \multirow[t]{10}{*}{ 8-9 Tahun } & Mudah patah semangat \\
\hline & Bangga terhadap kompetensi diri sendiri \\
\hline & $\begin{array}{l}\text { Mulai mengidentifikasi aktivitas dan kemampuan tertentu } \\
\text { sebagai karakter yang maskulin atau feminin }\end{array}$ \\
\hline & $\begin{array}{l}\text { Argumentatif dan suka mengatur, namun bisa responsif serta } \\
\text { murah hati sekaligus }\end{array}$ \\
\hline & $\begin{array}{l}\text { Telah mengembangkan kemampuan untuk mengatur emosi } \\
\text { sendiri }\end{array}$ \\
\hline & $\begin{array}{l}\text { Mulai melihat beberapa hal dari sudut pandang anak lain, namun } \\
\text { masih memiliki masalah dalam memahami perasaan serta } \\
\text { kebutuhan orang lain }\end{array}$ \\
\hline & $\begin{array}{l}\text { Menikmati bermain maupun menciptakan permainan dengan } \\
\text { beragam peraturan }\end{array}$ \\
\hline & $\begin{array}{l}\text { Cenderung mampu bekerjasama serta suka ketika diberi } \\
\text { tanggung jawab }\end{array}$ \\
\hline & Cenderung terikat pada figur-figur orangtua \\
\hline & $\begin{array}{l}\text { Berteman dengan teman-teman berjenis kelamin sama, biasanya } \\
\text { pertemanan didasarkan atas alasan kedekatan, hobi dan kesukaan } \\
\text { yang sama serta lingkaran pertemanan anak perempuan } \\
\text { cenderung lebih sedikit namun lebih dekat secara emosional }\end{array}$ \\
\hline
\end{tabular}

Tabel 3

Perkembangan Sosial Emosional Anak pada Usia 11-12 Tahun

\begin{tabular}{|l|l|}
\hline Umur/Tahun & Perkembangan Sosial Emosial \\
\hline 11-12 Tahun & Jauh lebih mampu mengekpresikan atau menahan emosi \\
\cline { 2 - 3 } & $\begin{array}{l}\text { Mulai mengalami perubahan emosiyang tiba-tiba dan dramastis } \\
\text { karena pubertas (terutama bagi anak perempuan yang mengalami } \\
\text { masa pubertas lebih cepat dari anak laki-laki) }\end{array}$ \\
\cline { 2 - 2 } & Cenderung bersikap sensitif terhadap kritikan \\
\cline { 2 - 2 } & $\begin{array}{l}\text { Lebih memilih untuk menghabiskan waktu bersama teman- } \\
\text { temannya }\end{array}$ \\
\cline { 2 - 2 } & $\begin{array}{l}\text { Lebih suka berteman dengan teman-teman bergender sama dan } \\
\text { berhati-hati terhadap lawan jenis }\end{array}$ \\
\cline { 2 - 2 } & $\begin{array}{l}\text { Menyerah pada tekanan dari teman-teman sebaya serta mulai } \\
\text { memiliki keinginan untuk berbicara, berpakaian dan bersikap } \\
\text { seperti teman-temannya }\end{array}$ \\
\hline
\end{tabular}


Program Sekolah Adiwiyata untuk menumbuhkan Cinta Lingkungan kepada peserta didik, program ini menyiapkan peserta didik dalam generasi yang lebih baik. Tentu pihak sekolah berkoordinasi dengan warga sekolah dan orang tua demi terwujudnya cita-cita tersebut. Kajian penelitian yang dilakukan Penulis menekankan pada aspek psikologi pengembangan sosio-emosional anak. Pada dasarnya Perkembangan sosial emosional merupakan dasar perkembangan kepribadian individu kelak dan berhubungan positif dengan perkembangan aspek-aspek lainnya. Perkembangan sosial emosional yang positif atau baik merupakan prediktor untuk kesuksesan dalam bidang akademik, kognitif, sosial dan emosional dalam kehidupan anak selanjutnya

\section{METODE PENELITIAN}

Penelitian ini adalah penelitian lapangan (field reaserch) yakni mengadakan pengamatan langsung dengan obyek yang diteliti dan dilakukan pengumpulan data yang ditemukan di lapangan. Pendekatan yang digunakan dalam penelitian ini adalah pendekatan kualitatif yang dikenal juga dengan pendekatan naturalisti. Pendekatan kualitatif yaitu penelitian yang menggambarkan keadaan yang ada di lapangan. Pendekatan kualitatif bersifat induktif, peneliti membiarkan permasalahan-permasalahan muncul dari data atau dibiarkan terbuka untuk interpretasi. Teknik pengumpulan data menggunakan wawancara dan dokumentasi. Data dihimpun dengan pengamatan yang seksama, mencakup deskripsi dalam konteks yang mendetil diserta catatan-catatan hasil wawancara yang mendalam, serta hasil analisis dokumen dan catatan-catatan (Sukmadinata, 2015)

Sedangkan metode penelitian ini menggunakan metode deskriptif. Penelitian deskriptif adalah penelitian yang bermaksud untuk membuat deskripsi mengenai situasisituasi atau kejadian-kejadian (Suryabrata, 2014). Peneliti berusaha memberikan informasi secara keseluruhan dan keadaan yang sedang berlangsung pada saat penelitian dilakukan secara sistematis.

Penelitian ini berupaya menganalisis hasil yang dicapai dari Implementasi Program Sekola Adiwiyata dalam Pengembangan Sosio-Emosional Anak Sekolah Dasar DI SDN Ngupasan Yogyakarta. Analisis data digunakakan melalui metode deskriptif. Peneliti melakukan penelitian langsung ke lokasi untuk mendapatkan dan mengumpulkan data. Peneliti harus mampu memahami fenomena tentang apa yang dialami subjek sehingga menghasilkan data deskriptif berupa kata-kata yang tertulis atau lisan dan perilaku yang diamati.

\section{HASIL PENELITIAN DAN PEMBAHASAN}

\section{Implementasi Sekolah Ramah Lingkungan dalam Pengembangan Sosio Emosional Anak Usia Dasar}

Untuk mencapai tujuan program Adiwiyata tersebut, maka ditetapkan empat komponen program yang menjadi satu kesatuan utuh dalam mencapai sekolah Adiwiyata, yaitu (1) Kebijakan Berwawasan Lingkungan. (2) Implementasi Kurikulum Berwawasan Lingkungan. (3) Kegiatan Lingkungan Berbasis Partisipatif. (4) Pengelolaan Sarana Pendukung Ramah Lingkungan (Anonimous, 2013). Dari pelaksanaan indikator tersebut akan menjawab kontribusi dari Program sekolah ini terhadap Pengembangan sosio emosional anak di SDN Ngupasan Yogyakarta.

\section{Kebijakan Berwawasan Lingkungan}

\section{a. Kebijakan Sekolah Membentuk Tim Adiwiyata Sekolah}

Langkah untuk mewujudkan program Adiwiyata adalah dengan membentuk suatu kepanitian Adiwiyata sekolah sesuai dengan pedoman Adiwiyata 2013. SDN Ngupasan Yogyakarta membentuk sendiri suatu kepanitiaan yang melibatkan beberapa pihak seperti 
orang tua peserta didik yang tergabung menjadi Paguyuban sekolah dan komite sekolah. Ibu Menik adalah koordinator Tim Adiwiyata sekaligus wali kelas IVb.

Hasil wawancara dengan orang tua peserta didik yaitu Ibu Tari yang termasuk menjadi anggota TIM SRA dan Adiwiyata di SDN Ngupasan Yogyakarta menjelaskan "bentuk acara dan kegiatan yang ada di sekolah selalu bekerjasama dengan orang tua peserta didik, karena pada umumnya orang tua susah untuk berkumpul, berkat ada paguyuban dan tim dari SRA dan Adwiyata ini menjadikan hubungan kerjasama sangat baik". Jadi dalam hal ini SDN Ngupasan Yogyakarta sudah menjalankan kerjasama baik dengan semua warga sekolah. Daftar nama dan susunan dari TIM Adiwiyata ini diperjelas dengan hasil dokumentasi yang sudah peneliti lampirkan

Sesuai dengan penjelasan Syamsu Yusuf dan Nani M Sugandhi bahwa faktor yang mempengaruhi perkembangan adalah sekolah yang menciptakan suasana hubungan sosio emosonal antar warga sekolah dan orang tua dengan harmonis. Karena dengan demikian kegiatan yang ada di Sekolahdidukung penuh oleh orang tua dan merasa saling memiliki terhadap kegiatan sekolah tersbut. Selain itu visi misi sekolah juga dapat terlaksana tidak hanya di sekolah melainkan juga di rumah.

\section{b. Perumusan Visi, Misi, dan Tujuan Sekolah Yang Memuat Pengelolaan Lingkungan Hidup}

Dalam indikator dari sekolah Adiwiyata Visi Misi dan Tujuan Sekolah harus memuat upaya perlindungan lingkungan hidup. Hal ini sesuai dengan hasil dokumentasi dan observasi peneliti bahwa dalam rangka mensosialisasikannya kepada warga sekolah dengan menempel disetiap ruang kelas dan poster besar di depan Sekolah. Seperti yang dituliskan visi, misi, dan tujuan SDN Ngupasan Yogyakarta berikut;

\section{c. Kebijakan Sekolah dalam Membangun Kemitraan Lingkungan Hidup}

SDN Ngupasan Yogyakarta menjalin kerja sama dengan beberapa pihak terkait upayanya untuk mewujudkan program Adiwiyata. Sebelum kerjasama dengan pihak luar SDN Ngupasan Yogyakarta meningkatkan peran dengan orangtua/wali peserta didik, komite, Paguyuban, dan seluruh warga sekolah dalam melaksanakan acara PPLH (pendidikan Perlindungan Lingkungan Hidup). Sedangkan SDN Ngupasan Yogyakarta menjalin hubungan kerja sama partisipatif dengan beberapa instansi luar seperti Dinas Lingkungan Hidup Yogyakarta, lingkungan masyarakat, Puskesmas Gondomanan. Hal ini seperti yang dijelaskan Syamsu Yusuf dan Nana M Sugandhi sebagai faktor yang mempengaruhi perkembangan yaitu bentuk komitmen sekolah terhadap visi, misi, dan tujuan sekolah.

\section{d. Kebijakan Sekolah dalam Mengimplementasikan Kurikulum Berwawasan Lingkungan}

SDN Ngupasan Yogyakarta mengimplementasikan kurikulum berwawasan lingkungan secara integralistik. Artinya setiap mata pelajaran dikaitkan dengan pembelajaran lingkungan hidup. Implementasi kurikulum berwawasan lingkungan dapat dilihat dari proses pembelajaran yang berinteraksi dengan alam, menjadikan alam sebagai sumber belajar, dan mengembangkan instrumen penilaian yang memuat upaya perlindungan lingkungan. Hal ini dapat dilihat dari dokumentasi yang peneliti dapatkan yaitu berupa RPP (Rencana Pelaksanaan Pembelajaran) kelas III semester 2. Sesuai dengan penjelasan Carolyn Maggit untuk meningkatkan perkembangan sosio emosional anak usia dasar lembaga yang bersangkutan menyediakan dorongan semangat yang realistis.

\section{e. Penyediaan Fasilitas Pendukung Pembelajaran Lingkungan Hidup}

Untuk mewujudkan pembelajaran lingkungan hidup yang efektif, SDN Ngupasan Yogyakarta membangun beberapa fasilitas sarana pembelajaran lingkungan hidup. Hasil obervasi peneliti melihat beberapa fasilitas yang sekolah berikan berupa taman dan kebun sekolah, tanaman obat keluarga, kolam ikan, dan sebagainya. Sarana-sarana tersebut digunakan sebagai tempat dan sumber belajar bagi peserta didik SDN Ngupasan Yogyakarta. 
dari penyediaan fasilitas pendukung tersebut diharapkan dapat meningkatkan kualitas pembelajaran. Karena peserta didik akan berinteraksi secara langsung dengan alam dan juga mengingat bahwa SDN Ngupasan Yogykarta adalah sebagai sekolah rintisan Adiwiyata. Sesuai penjelasan Carolyn Maggit sama halnya dengan mengimplementasikan kurikulum berwawasan lingkungan, penyediaan fasilitas ini juga termasuk dalam rangka untuk meningkatkan dorongan semangat yang realistis anak.

\section{f. Kebijakan Pengelolaan dan Penghematan Sumber Daya Sekolah}

Kebijakan SDN Ngupasan Yogyakarta sebagai sekolah rintisan Adiwiyata salah satunya adalah pengelolaan dan penghematan sumber daya lingkungan. Seperti pembersihan lingkungan, pengelolaan sampah terpilah, pemakaian listrik dan air secara efisien, penghijauan lingkungan, dan pemeliharaan sarana pendukung sekolah. dalam rangka penghematan sumber daya dilakukan dengan kebijakan pemanfaatan penggunaan listrik dan air.

Untuk penerangan kelas di SDN Ngupasan Yogyakarta cukup memiliki ventilasi udara dan kondisi kelas yang terang. Dalam pengelolaan lingkungan ini SDN Ngupasan Yogyakarta melibatkan peran seluruh warga sekolah baik itu guru, karyawan, peserta didik yang terlibat didalamnya. Dalam bukunya Carolyn Maggit menjelaskan upaya untuk meningkatakan perkembangan sosio emosional anak yaitu dengan meningkatkan sopan santun dengan menetapkan aturan sederhana.

\section{g. Kebijakan Pendanaan Pengelolaan Lingkungan Sekolah}

SDN Ngupasan Yogyakarta berkomitmen untuk mewujudkan program Adiwiyata dalam kebijakan pendanaan/bantuan didapatkan oleh Dinas Lingkungan Hidup kota Yogyakarta.

Ibu menik menjelaskan masalah anggaran dana terkait sekolah ini dipakai untuk pelatihan berwawasan Lingkungan. Sebagai data praobservasi hasil wawancara dengan Ibu menik "bahwa sebelum ada program Adiwiyata ini warga sekolah tidak tahu bagaimana cara pemanfaatan sampah, pengolahan sampah biopori dan lain-lain, Setelah sekolah ini menjadi sekolah rintisan adiwiyata. Dana yang didapat langsung digunakan untuk kebutuhan atau penunjang dari program berwawasan lingkungan ini seperti pengelohan sampah dan daun dan pemberian alat dari Dinas Lingkungan Hidup (DLH), yang baru-baru ini bantuan dari DLH adalah membuat sumur resapan sebagai penanggulangan Banjir. Kerjasama dengan DLH Tidak lepas dari rasa saling percaya, jadi untuk mencek sumur serapan ini dimanfaatkan dengan semestinya atau tidak". ${ }^{1}$

Selain berupa fisik bantuan tersebut berupa workshop dari Dinas Lingkungan Hidup (DLH) dalam rangka sosialisasi kepada warga sekolah seperti perwakilan guru kelas, perwakilan murid dan warga sekolah lainnya, jadi dari perwakilan tersebut bentuk informasinya berakar kebawah. Guru ke guru, guru ke peserta didik, peserta didik ke peserta didik dan seterusnya.

\section{Pelaksanaan Kurikulum Berbasis Lingkungan}

SDN Ngupasan Yogyakarta mengimplementasikan kurikulum berwawasan lingkungan secara integratik (integrated curriculum). Maksudnya adalah pelajaran kepedulian lingkungan selalu disisipkan dalam setiap mata pelajaran lain. Dalam pembelajarannya guru mengangkat tema atau nilai cinta terhadap lingkungan. Pelaksanaan ini melibatkan partisipasi dari seluruh guru. Karena guru yang menjalankannya pada kegiatan pembelajaran di kelas seperti.

\section{a. Pelaksanaan KBM Menggunakan Lingkungan Sekolah Sebagai Sumber Belajar}

${ }^{1}$ Wawancara dengan Ibu Menik, Wali Kelas IVb dan koordinator TIM Adiwiyata, pada 20 Desember 2018 di Lapangan Sekolah. 
Cara yang digunakan guru bermacam-macam melalui beberapa cara metode dan strategi contohnya seperti wali kelas IV yaitu Ibu Menik yang sering menggunakan kegiatan diskusi, observasi lapangan dan lainnya dengan selalu memasukkan unsur bermain atau kegiatan yang bermakna sesuai dengan kehidupan peserta didik tersebut didalam cara mengajar guru. Hasil dari wawancara dengan ibu Menik beliau mengatakan bahwa dengan strategi yang diberikan unsur bermain/kegiatan bermakna itu akan menumbuhkan rasa senang, selalu ingin tahu, dan menikmati dalam pembelajaran. Karena pada dasarnya peserta didik tidak terbebani atas prilaku atau kegiatan yang diberikan guru tersebut, contoh pada hasil wawancara ini.

Dalam kegiatan pembelajaran guru dapat menyesuaikan dengan tema yang berkaitan tentang cinta lingkungan. Dalam penjelasan Ibu Menik pada hasil wawancara menjelaskan "misalnya pada kelas saya tentang materi penanaman dan pemeliharan maka guru meminta peserta didik membawa tanaman dari rumah perkelompok dan tindak lanjutnya dengan menjaga dan merawat sesuai kelas masing-masing" ${ }^{2}$. Tidak hanya kelas tinggi kelas rendah juga melakukan hal yang sama, seperti membawa daun kering untuk dijadikan bingkai bersama kertas dan ditempel didalam kelas. Contoh lain seperti materi memelihara hewan, ikan burung dipelihara, anak-anak sendiri yang bertindak atas pengawasan guru. Sesuai dengan penjelasan Syamsu Yusuf fan Nana M Sugandhi bahwa Cara dan tehnik yang dipakai oleh seorang guru mempunyai kepedulian untuk menciptakan suasana proses belajar mengajar yang menyenangkan.

Dalam perkembangan sosio emosional anak indikator usia 8-9 tahun dan 11-12 tahun bahwa anak mampu mengontrol emosinya. Khanin dan Bunga sesuai penjelasannya mampu menjadikan predikat sebagai kaka kelas untuk kelas rendah sebagai contoh terbukti dari wawancara dengan Bunga "Malu ketika kelas kotor dan membuang smapah sembarangan"3 dan Khanin "malu apabila sampai ditegur guru dan kelihatan oleh adik kelas membuang sampah sembarangan"4. Jadi dalam indikatornya peserta didik bersama-sama menjaga lingkungan agar selalu tetap indah. Hal ini sesuai dengan hasil observasi peneliti yang menemukan bahwa di kelas dan lingkungannya bersih dan rapi.

\section{b. Pemanfaatan Barang Bekas}

Sesuai dalam bukunya Carolyn Maggit pada poin meningkatakan dorongan semangat yang realistis anak. Ketika kita berbicara tentang ramah lingkungan artinya mampu untuk memanfaatkan barang bekas menjadi sesuatu barang yang dapat dimanfaatkan. Di SDN Ngupasan Yogyakarta dalam hal ini guru memberikan dorongan semangat yang realistis. Sekolah lebih khusus adalah guru mengajak peserta didik untuk mencintai lingkungan dengan cara yang bisa dilakukan oleh peserta didik seperti membuat kerajinan atau daur ulang dari bahan bekas. Hasilnya peserta didik mampu membuat pot bunga dari botol bekas, membuat hiasan dinding dari plasttik bekas dan membuat hiasan atap dari sedotan minum, dll. Hasil observasi peneliti melihat banyak hiasan-hiasan di kelas atau lingkungan sekitarnya yang terbuat dari barang bekas.

Dalam perkembangan sosio emosional anak indikator usia 7-8 tahu bahwa anak bersahabat dan bekerjasama, dan pada perkembangan sosio emosional anak indikator usia 8-9 tahun cenderung mampu bekerjasama serta suka ketika diberi tanggung jawab. Pada indikator perkembangan tersebut bahwa anak memliki sifat bekerjasama. Pada kegiatan diatas mengharuskan anak berkelompok penjelasan dari Ibu Tiyas bahwa anak saling bekerjasama membuat pot bunga dengan pembagian tugas masing-masing dan tentunya dengan bimbingan guru sebagai pengawasnya. Peneliti menanyakan kepada peserta didik lain apakah pernah

\footnotetext{
${ }^{2}$ Wawancara dengan Ibu Menik, Wali Kelas IVb dan koordinator TIM Adiwiyata, pada 20 Desember 2018 di Lapangan Sekolah.

${ }^{3}$ Wawancara dengan Bunga, Peserta Didik Kelas Vb pada 16 januari 2019 di kantor sekolah.

${ }^{4}$ Wawancara dengan Khanin, peserta didik kelas IVb, pada 16 januari 2019 di perpusatakaan sekolah.
} 
mengadakan kegiatan tersebut jawabannya pernah. Seperti Khanin kelas IVb membuat daur ulang sampah plastik menjadi baju atau rompi dan Khalim kelas $3 \mathrm{~b}$ membuat pot bunga dari botol plastik. Khalim menjelaskan "perasaannya senang, saya bertugas memotong botol plastik" dalam kegiatan langung peran seoang guru sangat dibtuhkan dalam mengontrol dan membimbng peserta didik agar tepat sasaran sesuai tujuan pembelajaran.

Dalam perkembangan sosio emosional anak indikator usia 7-8 tahun bahwa anak dapat mengikuti sebuah kejadian dari awal hingga akhir serta sensitif terhadap kebutuhan orang lain, dan pada perkembangan sosio emosional anak indikator usia 8-9 tahun bahwa anak argumentatif, dan suka mengatur, namun bisa resposif serta murah hati sekaligus. Pada indikator tersebut dari didikan wali kelasnya peserta didik mampu untuk responsif atas kebutuhan teman lain. Khanin adalah peserta didik Ibu Menik kelas IVb dari hasil wawancara dengan peneliti. "ketika pembelajaran daur ulang sampah plastik ada teman saya yang tidak membawa karena kelupaan, kebetulan saya memliki sampah plastik yang lebih saya berikan ke dia" 6 dari penjelasan Khanin tersebut diketahui bahwa Khanin responsif atas kebutuhan orang lain. dalam hal ini tidak terlepas dari peran guru yang selalu menanamkan nilai-nilai sosial dan berbagi kepada teman sebaya dan sekitarnya.

\section{c. Mengkomunikasikan Hasil Karya Inovasi Peserta Didik Melalui Gambar dan Buletin Sekolah.}

Hasil observasi yang dilakukan peneliti dapat dilihat bahwa cara mengkomunikasikan hasil karya inovasi peserta didik melalui majalah, dan buletin sekolah. selain menanamkan rasa cinta lingkungan dalam bentuk kerajianan. Guru juga meminta dalam hal karya tulis seperti gambaran dan kliping tentang lingkungan.

Sesuai dalam bukunya Carolyn Maggit pada poin meningkatakan dorongan semangat yang realistis. Mengkomunikasikan hasil karya inovasi peserta didik melalui hasil karya tulis gambaran atau kliping sekolah. selain menanamkan rasa cinta lingkungan dalam bentuk kerajianan. Guru juga meminta dalam hal karya tulis seperti gambaran atau kliping tentang lingkungan.

Perkembangan sosio emosional anak indikator usia 7-8 tahun bahwa anak dapat memainkan permainan yang memakai aturan, dan pada perkembangan sosio emosional anak indikator usia 8-9 tahun bahwa anak menikmati bermain maupun menciptakan permainan dengan beragam peraturan. Pada indikator tersebut anak kelas rendah sepeti Khalim menjelaskan "ibu guru pernah membawa contoh dari aktivitas gempa dan kami melihat dan mempraktekkannya". 7 Dalam penjelaskan tersebut Khalim dapat memainkan permainan yang memakai aturan yang mana pada prakteknya guru memberikan contoh dan membimbing peserta didik untuk melakukannya dengan baik dan benar agar tujuan pembelajaran tercapai. Pada kelas tinggi dijelaskan oleh Khanin dan Bunga pernah praktek tersebut tetapi untuk kelas tinggi peserta didik yang membuatnya dengan berkelompok. dari penjelasan Khanin "pernah di kelas membuat kelompok mendaur ulang dari bahan kardus membuat miniatur tanah longsor". 8

\section{d. Pengembangan Isu Lingkungan}

Bentuk kepedulian SDN Ngupasan Yogyakarta atas kejadian bencana alam seperti yang ada di Dunggala juga ikut berpartisipasi warga sekolahnya bersama-sama berdoa menunjukkan sikap peduli dan dalam wujud sumbangan uang dan pakaian bekas untuk semua warga sekolah SDN Ngupasan Yogyakarta yang menhasilkan dana kurang lebih 10 Juta atas bantuan oleh warga sekolah tak terkecuali peserta didik. Resepon dari warga sekolah sebagai

\footnotetext{
${ }^{5}$ Wawancara dengan Khalim, Kelas IIIb, pada 16 januari 2019 di Perpusatakaan Sekolah.

${ }^{6}$ Wawancara dengan Khanin, Peserta Didik Kelas IVb, pada 16 Januari 2019 di Perpusatakaan Sekolah.

${ }^{7}$ Wawancara dengan Khalim, Kelas IIIb, pada 16 januari 2019 di Perpusatakaan Sekolah.

${ }^{8}$ Wawancara dengan Khanin, peserta didik kelas IVb, pada 16 januari 2019 di perpusatakaan sekolah. 
role model yang baik kepada semua peserta didik menjadikan responnya itu bagus. Dalam Perkembangan sosio emosional anak indikator umur 7-8 tahun bahwa anak memiliki pemahaman sosial yang lebih luas, dapat merasa terganggu dengan program pemberitaan yang menampilkan kekerasan atau benacana alam. hasil wawancara dengan Gladis 1a, Nazwa $2 \mathrm{~b}$ dan Khalim $3 \mathrm{~b}$ menyatakan ikut menyumbang atas bencana yang terjadi. Kata Khalim "yang penting Ikhlas" dan Gladis dan Nazwa merasa sedih atas kejadian tersebut.

Perkembangan sosio emosional anak indikator umur 7-8 tahun bahwa anak memiliki pemahaman sosial yang lebih luas, dapat merasa terganggu dengan program pemberitaan yang menampilkan kekerasan atau benacana alam. Dalam contoh kecilnya ketika teman satu kelas sakit, perlakuannya berbeda-beda Gladis dengan menjenguk sedangkan Nazwa dan Khalim dengan mengantar ke UKS. Sesuai dengan perkembangan sosio emosional anak indikator umur 8-9 tahun bahwa anak cenderung mampu bekerjasama serta suka ketika diberi tanggung jawab.

\section{Kegiatan Lingkungan Berbasis Partisipatif}

SDN Ngupasan Yogyakarta melibatkan seluruh warga sekolah dalam pelaksanaan kegiatan lingkungan ini. Kegiatan lingkungan partisipatif warga sekolah di SDN Ngupasan Yogyakarta dapat dilihat dari beberapa program yang telah berjalan sebagai berikut:

\section{a. Program Jum'at bersih}

Program Jum'at bersih merupakan salah satu kegiatan lingkungan partisipatif yang dilakukan di SDN Ngupasan Yogyakarta. Jum'at bersih di SDN Ngupasan Yogyakarta sementara ini masih belum terjadwal secara rutin melainkan tergantung kondisi yang ada di Sekolah. Hasil Observasi peneliti dalam pelaksanaannya, guru dan peserta didik secara bersama-sama membersihkan lingkungan sekolah baik itu ruang kelas, halaman, kebun sekolah, kamar mandi, dan fasilitas lain. Bahkan dalam kegiatan jum'at bersih ini peserta didiklah yang membersihkan dan mencuci tempat sampah kelas. Selain itu dalam kegiatan jum'at bersih ini peserta didik menanam dan membersihkan taman kelas. Kegiatan ini merupakan kegiatan dalam rangka membudayakan kepedulian bagi warga sekolah khususnya bagi peserta didik.

Dalam perkembangan sosio emosonal anak indikator usia 7-8 tahun bahwa anak bersahabat dan bekerjasama, dan indikator usia 8-9 tahun bahwa anak cenderung dapat berkerjsama ketika diberi tanggung jawab. Pada aktivitas jumat bersih anak-anak semua menjalankan tugasnya masing-masing perkelas sesuai instruksi dari wali kelasnya. Sedangkan pada indikator usia 8-9 tahun dan 11-12 tahun bahwa anak berteman dengan teman berjenis sama. Peneliti melihat bahwa cenderung ketika bersih-bersih kelas atau kegiatan yang melibatkan banyak orang bahwa kebanyakan anak-anak cenderung untuk berkumpul kepada teman sesama jenis atau teman kelompok saja khsusunya kelas atas. Karena untuk kelas rendah sesuai dengan hasil wawancara, Gladis, Nazwa dan Khalim berteman dengan laki-laki dan perempuan. Sedangkan Bunga kelas 5 cenderung berteman dengan teman yang berjenis sama. Tetapi dalam keseluruhan anak dapat bekerjasama dengan baik antar teman sebayanya atau antar teman satu kelasnya dan cenderung bertanggung jawab atas pemberian tugas yang diberikan. Hasil Observasi saling bekerjasama dan dalam kegiatannya pada peserta didik kelas atas cenderung berkelompok dengan teman yang bergender sama.

\section{b. Penghematan Sumber Daya}

SDN Ngupasan Yogyakarta melakukan penghematan sumber daya melalui adanya kebijakan sekolah. Kebijakan sekolah tersebut diantaranya adalah kebijakan penghematan listrik dan air. Tidak menyalakan lampu pada saat siang hari kecuali mendung atau ada jadwal penggunaan LCD di kelas. Dalam pengelolaan lingkungan ini SDN Ngupasan Yogyakarta melibatkan peran seluruh warga sekolah baik itu guru, karyawan, dan peserta didik yang terlibat di sekolah tersebut. Bentuk sosialisasinya sekolah memasng poster hemat energi. Hal ini sesuai dengan hasil observasi di SDN Ngupasan Yogyakarta tentang penghematan energi. 
Dalam perkembangan sosio emosional bahwa anak dihadapkan atas tanggung jawab dan kerjasama saling mengingatkan terhadap menghemat sumber daya seperti disebutkan di atas. Khalim "saya pernah mematikan kipas angin ketika pulang sekolah", ${ }^{9}$ Bunga "saya menegur teman yang memainkan lampu kelas dan mematikannya" 10 . Sebagian besar anak mulai terbiasa dengan adanya pola kebiasaan tersebut. Bahwa anak yang belum terbiasa anak lain dapat salaing mengingatkan kepada temannya. Dalam perkembangan emosi untuk menciptakan suasana yang kondusif, sekolah harus menciptakan kondisi kelas yang tertib, bersih dan sehat sesuai dengan penjelasan Syamsu Yusuf dan Nani M Sugandhi.

\section{c. Pelaksanaan Piket Kebersihan}

Pelaksanaan Piket kebersihan di sosialisasikan melalui poster disekitar kelas dan disekitar tempat bermain dengan tulisan "SEMUTLIS" yaitu sepuluh menit untuk lingkungan sekolah dilakukan serentak pada jam 7:10 ketika bel berbunyi. Selain sosialisasi ada juga guru khusus yang ditunjuk sebagai pengawas dalam kegiatan piket kebersihan ini yaitu bapak Triagung. Karena pada pelaksanaannya terdapat peserta didik melanggar atau tidak mengikuti piket kebersihan maka akan mendapatkan teguran dan sangsi yang dicatat bapak Triagung di buku pengawas piket.

Dalam perkembangan sosio emosional anak indikator usia 7-8 tahun bahwa anak mampu bertanggung jawab, dan pada indikator usia 8-9 tahun bahwa anak cenderung mampu bekerjasama serta suka ketika diberi tanggung jawab Misalnya Ada yang tidak melaksanakan piket atau piketnya tidak sampai selesai hal tersebut akan dilaporkan temannya ke guru tindak lanjutnya guru tersebut yang menanyakan alasannya. Kegiatan piket kebersihan kelas dilaksanakan pada waktu pagi dan setelah pulang sekolah. Peneliti menanyakan kepada Khalim peserta didik kelas 3 terkait piket kelas "saya selalu mengerjakannya" dan ditanyakan kepada Khalim responya terhadap teman yang tidak piket "saya menegurnya". ${ }^{2}$ Bagitu juga Bunga yang mematuhi jadwal piket dan tanggapannya atas teman yang tidak piket "saya menegur teman dan menanyakan alasannya" 13 ketika peneliti menanyakan bunga cuma menegur teman sesama perempuan saja. Dalam hal ini masuk ke indikator usia 11-12 thun bahwa anak lebih suka berteman dengan teman bergender sama dan berhat-hati terhadap lawan jenis. Dari hasil observasi dapat dilihat ketika pulang sekolah peserta didik secara berkelompok melaksanakan piket kebersihan.Dijelaskan oleh Carolyn Maggit upaya dalam meningkatakan perkembangan sosio emosional anak pada poin pertama yaitu dengan memberikan dorongan semangat yang realistis dan pada poin kedua tetap tegas dan konsisten dengan aturan waktu.

\section{d. Pelaksanaan Lomba Kebersihan Kelas}

SDN Ngupasan Yogyakarta mengadakan lomba kebersihan kelas untuk waktu yang tidak ditentukan dalam pelaksanaan kegiatan lingkungan berbasis partisipatif. Pada hasil observasi yang dilakukan peneliti bahwa untuk lomba kebersihan kelas guru mengumumkan di waktu upacara karena pada waktu upacara adalah momen yang tepat tempat semua warga sekolah berkumpul.

Dalam perkembangan sosio emosional anak indikator usia 8-9 tahun bahwa anak cenderung mampu bekerjasama serta suka ketika diberi tanggung jawab. Pada indikator ini anak-anak berlomba-lomba untuk mendapatkan juara lomba kebersihan kelas. pelaksanaannya peserta didik saling mengingatkan untuk membuang sampah sesuai tempatnya dan menjaga kebersihan kelas oleh karena itu kerjasama dan tanggung jawab jadwal piket dijalankan sebaik-baiknya Khanin "saling menegur dengan teman apabila ada teman yang tidak ikut

\footnotetext{
${ }^{9}$ Wawancara dengan Khalim, Kelas IIIb, pada 16 januari 2019 di Perpusatakaan Sekolah.

${ }^{10}$ Wawancara dengan Bunga, peserta didik kelas Vb, pada 16 januari 2019 di perpusatakaan sekolah.

${ }^{11}$ Wawancara dengan Khalim, Kelas IIIb, pada 16 januari 2019 di Perpusatakaan Sekolah.

${ }^{12}$ Wawancara dengan Khalim, Kelas IIIb, pada 16 januari 2019 di Perpusatakaan Sekolah.

${ }^{13}$ Wawancara dengan Bunga, peserta didik kelas Vb, pada 16 januari 2019 di perpusatakaan sekolah.
} 
piket"14. Pada perkembangan sosio emosional anak usia 11-12 tahun bahwa anak cenderung bersikap sensitif terhadap kritikan. Seperti kelas Bunga pernah juara kebersihan kelas maka mareka akan berusaha mempertahankan gelar itu di kelasnya. Sesuai pada penjelasan Carolyn Maggit bahwa upaya untuk meningkatakan perkembangan sosio emsional anak pada poin pertama yaitu dengan memberikan dorongan semangat yang realistis. Dan poin kedua untuk menetapkan lalu pertahankan batasan yang jelas mengenai prilaku anak.

\section{e. Pemanfaatan lingkungan dan Tanaman Sekolah}

Pemanfaatan lingkungan dan tanaman sekolah di SDN Ngupasan Yogyakarta. Hasil observasi peneliti terdapat tanaman-tanaman disekitar kelas yang dibawa oleh peserta didik dan tanaman dari sekolah sendiri. Tanaman dari peserta didik biasanya menyesuaikan dengan tema yang diangkat sesuai dengan materi yang akan dibahas. Sekolah Adiwiyata juga dapat memanfaatkan lahan dan fasilitas sekolah sesuai kaidah-kaidah perlindungan dan pengelolaan lingkungan seperti pemeliharaan taman, tanaman obat keluarga, kolam, dan pengelolaan sampah.

Pada tanaman obat keluarga peserta didik disosialisasikan jenis tanaman obat dan fungsi obat tersebut pada kegiatan pembelajaran sehingga peserta didik paham atas kegunaannya. Kegunaan obat tersebut dapat dimanfaatkan oleh peserta didik. Pada penjelasan Ibu Menik "Contoh ketika mereka menolong temannya seperti mimisan mereka langsung untuk pergi ke tanaman obat dan langsung mengambil sirih untuk mengatasi penyakit temannya tersebut". Selain itu secara sedehana bentuk kepedulian peserta didik kepada teman sebayanya pada penjelasan Ibu Menik "kepedulian lainnya ketika temannya masuk angin teman lainnya langsung mengambil teh hangat". Jadi dalam konteks ini Kepekaan sosial kepada temannya sangat terasa, hal itu tidak terlepas dari peran lingkungan dan arahan oleh guru dalam mensosialisasikan untuk ramah lingkungan dan ramah anak kepada teman sebayanya.

Dalam perkambangan sosio emsoional anak indikator usia 8-9 tahun bahwa anak responsif serta murah hati sekaligus, dan pada perkembangan sosio emosional anak indikator usia 11-12 tahun bahwa anak jauh lebih mampu mengekspresikan atau menahan emosi. Terlihat dari kegiatan di atas Khanin peduli dengan temannya yang sakit dan responsif ketika temannya membutuhkan obat sirih yang di ambil dari tanaman obat untuk obat mimisan. Khanin "saya dibantu dengan teman"15.

\section{f. Pengolahan sampah}

Pengolahan sampah merupakan agenda lingkungan yang dilaksanakan secara partisipatif di SDN Ngupasan Yogyakarta. Sampah tersebut diolah untuk dijadikan sesuatu yang bermanfaat. Pengolahan sampah ini melibatkan seluruh warga sekolah baik itu guru, peserta didik, karyawan dan juga petugas kebersihan. Hasil observasi peneliti untuk hasil dari pemanfaatan sampah bisa dilihat berupa pot bunga atau hiasan indor atau outdor di sekolah serta dapat dijadikan mainan. pengolahan tersebut hasil dari bentuk olahan individu atau kerjasama kelompok peserta didik yang dibimbing oleh guru dan ada juga secara khsusus yang dbuat oleh guru seperti bentuk miniatur bencana alam sebagai media pembelajaran. Ibu Menik Menyebutkan "Sebelum menjadi sekolah adiwiyata sampah-sampah itu dibuang dan sekarang setelah menjadi sekolah adiwiayata sampah tersebut dimanfaatkan untuk menjadi barang yang lebih berguna sebagai pengelolanya adalah ibu Rike yang bertugas untuk daur ulang guru kelas ". ${ }^{16}$

Dalam perkembangan sosio emosional anak indikator usia 7-8 tahun bahwa anak lebih percaya dan mandiri. Dalam hal ini untuk kelas rendah kelas Khalim diminta untuk membuat

\footnotetext{
${ }^{14}$ Wawancara dengan Khanin, peserta didik kelas IVb, pada 16 januari 2019 di perpusatakaan sekolah.

${ }^{15}$ Wawancara dengan Khanin, peserta didik kelas IVb, pada 16 januari 2019 di perpusatakaan sekolah.

${ }^{16}$ Wawancara dengan Ibu Menik, Wali Kelas IVB dan koordinator Tim Adiwiyata pada 20 Desember 
pot Bunga dari botol plastik tanggapan Khalim "kami senang membuatnya" 17 anak-anak lebih percaya dengan teman kelompoknya dan mandiri dalam pembuatannya karena bangga dengan kemampuan diri sendiri dan kelompok. Penjelasan dari Carolyn Maggit dalam upaya untuk meningkatakan perkembangan sosio emosional anak yaitu dengan memberikan banyak kesempatan untuk bermain secara bebas.

\section{g. Seminar Lingkungan}

Kegiatan Seminar di SDN Ngupasan Yogyakarta melibatkan instansi luar dalam hal narasumber. Kegiatan Seminar yang dilakukan antara lain adalah Seminar tentang lingkungan hidup oleh Dinas Lingkungan Hidup, Seminar tentang kebersihan diri dan lingkungan oleh Puskesmas Godomanan, dan seminar tentang Makanan sehat oleh BPOM dan Puskesmas Kota Yogyakarta. Pihak yang terlibat dalam kegiatan tersebut adalah semua warga sekolah termasuk orang tua yang diwakili dari paguyuban kelas, dari paguyuban kelas menyebar ke semua orang tua.

Dalam perkembangan sosio emosional anak indikator usia 8-9 tahun bahwa anak cenderung terikat pada figur-figur orang tua. Pada indikator ini dapat dilihat orang tua juga mengetahui tentang bagaimana lingkungan hidup dan kebersihan diri. Hal ini dapat berlanjut sosialisasi dan kebiasaan di rumah agar pemahaman peserta didik tidak cuma hanya di Sekolahsaja. Dalam wawancara dengan Ibu Tari "anak saya membersihkan tempat tidur sendiri dan dibiasakan sehabis makan mencuci piringnya sendiri" ${ }^{18}$. Wawancara dengan peserta didik, Bunga menjelaskan "di rumah saya menanam kacang dengan Ibu" ${ }^{19}$ sedangkan Gladis "saya menanam jeruk nipis dan bijinya ditanam sendiri". ${ }^{20}$ Dalam buku Carolyn Maggit menjelaskan upaya dalam meningkatkan perkembangan sosio emsoional anak terkait hal ini yaitu menjaga hubungan yang hangat dan terbuka dengan anak.

\section{Pengelolaan Sarana Pendukung Ramah Lingkungan \\ a. Pengelolaan tempat sampah}

SDN Ngupasan Yogyakarta menyediakan tempat sampah terpilah yaitu tempat sampah warna hijau untuk sampah daun, tempat sampah warna kuning untuk sampah kertas dan tempat sampah warna merah untuk sampah plastik. Jumlah tempat sampah cukup memadai hampir disetiap sudut kelas memiliki tempat sampah. Sehingga Peserta didik juga dibiasakan oleh guru dalam memilah sampah agar penggunaanya tepat sasaran. Pada saat penilaian kelas bersih dapat dilihat kelas yang paham dan belum dalam penggunaan tempat sampah terpilah nanti akan mendapatkan teguran dari guru bersangkutan atau wali kelasnya. Sarana kebutuhan kebersihan peserta didik telah dipenuhi oleh pengelola SDN Ngupasan Yogyakarta.

Perkembangan sosio emosional anak indikator usia 11-12 tahun bahwa anak cenderung bersikap sensitif terhadap kriktikan. Pada indikator ini Bunga menjawab "malu bila sampai ditegur guru" 21 kelas Bunga kelas $\mathrm{Vb}$ pernah mendapat juara kelas bersih. Hal ini menjadi konsen guru yang mana menciptakan penilaian yang adil dan objektif. Dari hasil observasi peneliti ditemukan tempat sampah dilingkungan kelas tinggi yaitu 45 dan 6 membuang sampah pada tempatnya dan tepat guna. Sedangkan tempat sampah kelas 12 dan 3 cukup bersih dan tepat guna walaupun ada sedikit yang membuang sampah tidak sesuai tempatnya.

\section{b. Pengelolaan kolam ikan, tanaman obat, kebun sekolah dll}

\footnotetext{
${ }^{17}$ Wawancara dengan Khalim, Kelas IIIb, pada 16 januari 2019 di Perpusatakaan Sekolah.

${ }^{18}$ Wawancara dengan Ibu Tari, Orang tua peserta didik kelas V bernama Wardana pada 16 januari 2019 di perpusatakaan sekolah.

${ }^{19}$ Wawancara dengan Bunga, peserta didik kelas Vb, pada 16 januari 2019 di perpusatakaan sekolah.

${ }^{20}$ Wawancara dengan Gladis, Kelas Ia, pada 16 januari 2019 di Perpusatakaan Sekolah.

${ }^{21}$ Wawancara dengan Bunga, peserta didik kelas Vb, pada 16 januari 2019 di perpusatakaan sekolah.
} 
Pengeolaan fasilitas tersebut berjalan dengan baik, Sekolah selalu melibatkan peran dari warganya dalam Pemeliharaan. Tetapi untuk pemeliharaan secara khusus dan terjadwal bagi peserta didik sekolah belum mempersipakan. Untuk pemeliharaan tidak terjadwal bagi peserta didik guru dapat menyesuaikan dengan materi dalam pembelajaran. Hasil observasi peneliti melihat bahwa lingkungan hidup seabagai sumber belajar tersebut terawat dan bersih.

Dalam perkembangan Indikator umur 8-9 tahun bahwa anak argumentatif dan suka mengatur, namun bisa responsif serta murah hati sekaligus. Hasil wawancara dengan Bapak Gusmianto bahwa anaknya pernah menegur temannya ketika berkunjung kerumah dan memetik daun dari tanamannya, hal itu terbentuk atas kebiasan yang sering ditanamkan di sekolah dan orangtuanya untuk mencintai lingkungan sekitar. Peneliti menanyakan kepada peserta didik bersangkutan yaitu dhiki "saya sering melihat bapak merawat tanaman". ${ }^{22}$

\section{c. Pemeliharaan sanitasi sekolah}

Pemeliharaan sanitasi SDN Ngupasan Yogyakarta dilakukan dengan membuat beberapa biopori, dan saluran air (selokan). Untuk mengatasi permasalahan sanitasi sekolah SDN Ngupasan Yogyakarta membuat sumur serapan atas saran tim penilaian Adiwiyata dan sebagai bantuan dari DLH untuk mengalirkan air agar tidak tergenang. Dampaknya peserta didik dan warga sekolah merasa aman dan nyaman ketika melaksanakan kegaiatan di sekolah dan belajar mengajar. Hasil observasi bahwa sumur serapan berjumlah 6 di SDN Ngupasan Yogyakarta.

\section{d. Pengelolaan Kantin Sehat}

Kesehatan memang sangat penting diperhatikan sekolah terbukti SDN Ngupasan Yogyakarta memiliki "Kantin sehat" yaitu kantin yang menjual makanan yang tidak mengandung boraks dan formalin. Kantin sehat ini diawasi oleh guru dan kepala sekolah agar makanan yang dijual merupakan makanan yang bersih dan sehat. Kantin sehat ini milik ibu Sekar Anim di SDN Ngupasan Yogyakarta yang telah mendapatkan sertifikat dari dinas kesehatan kota Yogyakarta bahwa makanan yang dijual aman.

Dalam perkembangan sosio emosional anak indikator usia 7-8 tahun bahwa anak dapat membantah dan berdebat dengan sudut pandangnya sendiri. Dalam indikator tersebut pada masalah anak yang bertanggung jawab mengembalikan peralatan makanan yang dipinjam dikantin. Khalim "saya pernah menegur teman yang tidak mengembalikan piring kekantin". ${ }^{23}$ Sedangkan Bunga "saya melihat ada gelas di kelas yang tidak dikembalikan teman, saya mengembalikannya ke kantin". ${ }^{24}$

\section{e. Pengelolaan air, listrik, dan ATK}

Kebijakan dalam mengelola air, listrik, dan ATK dapat dilihat dari beberapa langkah berikut. (1) Menampung air hujan. (2) Adanya IPAL (Instalasi Pengolahan Air Limbah) untuk menyiram tanaman, mencuci tempat sampah, mencuci mobil dll. (3) Pembiasaan hemat listrik di kelas.

\section{f. Pemeliharaan Toilet dan Kamar Mandi kebersihan kamar mandi}

Hasil Observasi peneliti bahwa SDN Ngupasan Yogyakarta mempunyai 2 kamar mandi dan 2 toilet untuk laki-laki dan perempuan serta toilet guru. Pemeliharaan kamar mandi dan toilet secara rutin dilakukan oleh petugas kebersihan sekolah yaitu bapak Gusmianto. Dan pembersihan yang tidak terjadwal dilaksanakan ketika kegiatan Jum'at bersih oleh warga sekolah.

\section{PENUTUP}

\footnotetext{
${ }^{22}$ Wawancara dengan Dhiki Rusnawan Putra, peserta didik kelas IIa, pada 16 januari 2019 di perpusatakaan sekolah.

${ }^{23}$ Wawancara dengan Khalim, Kelas IIIb, pada 16 januari 2019 di Perpusatakaan Sekolah.

${ }^{24}$ Wawancara dengan Bunga, peserta didik kelas Vb, pada 16 januari 2019 di perpusatakaan sekolah.
} 
Implementasi Sekolah Adiwiyata di SDN Ngupasan Yogyakarta berjalan dengan baik, pada tahap Pelaksanaanya meliputi (1) Kebijakan berwawasan Lingkungan, membentuk TIM Adiwiyata, Perumusan visi, misi, dan tujuan sekolah yang memuat pengelolaan lingkungan hidup, Membangun kemitraan lingkungan hidup, Mengimplementasikan kurikulum berwawasan lingkungan, Penyediaan fasilitas pendukung pembelajaran lingkungan hidup, pengelolaan dan penghematan sumber daya sekolah, dan Pendanaan Pengelolaan lingkungan sekolah. (2) Pelaksanaan Kurikulum berbasis lingkungan, seperti pelaksanaan KBM menggunakan sekolah sebagai sumber belajar, pemanfaatan barang bekas, mengkomunikasikan hasil karya inovasi peserta didik melalui gambar, dan buletin sekolah, serta pengembangan isu lingkungan. (3) Kegiatan lingkungan berbasis partisipatif, seperti program jumat bersih, penghematan sumber daya, pelaksanaan piket kebersihan, lomba kebersihan kelas, pemanfaatan lingkungan dan tanaman sekolah, pengolahan sampah, dan seminar lingkungan. (4) Pengelolaan sarana pendukung ramah lngkungan, seperti pengeloaan tempat sampah, kolam ikan, tanaman obat, kebun sekolah, sanitasi sekolah, kantin sehat, air, listrik, dan ATK, serta toilet dan kamar mandi.

Kontribusi dari Implementasi Program Sekolah Ramah Lingkungan dalam pengembangan sosio emosional anak usia dasar adalah anak mampu mengontrol emosi, saling membantu dan senang bekerjasama serta bertanggung jawab, responsif terhadap kebutuhan teman/lingkungan sekitar, dapat memainkan permainan memakai aturan dan dapat menciptakan peraturan sendiri, peduli sosial, sensitif, lebih percaya dan mandiri, cenderung terikat pada figur-figur orang tua.

\section{DAFTAR PUSTAKA}

Anonimous. (2013). Panduan Adiwiyata Sekolah Peduli Dan Berbudaya Lingkungan 2013. Jakarta: Kementerian Lingkungan Hidup.

Ira Rahmawati, I Made Suwanda. (2015). Upaya Pembentukan Perilaku Peduli Lingkungan Peserta didik Melalui Sekolah Adiwiyata Di Smp Negeri 28 Surabaya. Kajian Moral dan Kewarganegaraan. Vol 1 No 3.

Meggitt, Carolyn. (2012). Memahami Perkembangan Anak. Jakarta:Indeks.

Rismawati, Tri. (2013). Efektivitas Program Adiwiyata Sebagai Upaya Penanaman Rasa Cinta Lingkungan Di SMP Negeri 3 Malang. Malang: Universitas Negeri Malang.

Soetjiningsih, Christiana Hari. (2014). Perkembangan Anak, Jakarta: Prenada.

Sukmadinata, Nana Syaodih. (2015). Metode Penelitian Pendidikan. Bandung: Remaja Rosdakarya.

Suryabrata, Sumadi. (2014). Metodologi Penelitian. Jakarta: Raja Grafindo Persada. 